\title{
THE EFFECTIVENESS OF USING INFOGRAPHICS AS AN AID IN READING COMPREHENSION
}

\section{Revathy a/p Manickam*}

Sekolah Kebangsaan Jabor, Faculty of Education

Universiti Kebangsaan Malaysia, 43600 Bangi

Malaysia

revmanickam25@gmail.com

\section{Azlina Abdul Aziz}

Centre of Innovation in Teaching \& Learning, Faculty of Education

Universiti Kebangsaan Malaysia, 43600 Bangi

Malaysia

azlina1@ukm.edu.my

*Corrosponding author's Email: revmanickam25@gmail.com

Peer-review under responsibility of 4th Asia International Multidisciplinary Conference 2020 Scientific Committee http://connectingasia.org/scientific-committee/ (C) 2020 Published by Readers Insight Publisher, lat 306 Savoy Residencia, Block 3 F11/1,44000 Islamabad. Pakistan, editor@readersinsight.net This is an open access article under the CC BY-NC-ND license (http://creativecommons.org/licenses/by-nc-nd/4.0/). 


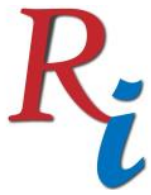

\section{Asia Proceedings of Social Sciences}

(APSS)

www.readersinsight.net/APSS

\section{A b s t r a c t}

Reading comprehension is a crucial skill that is needed in acquiring a language. However, the Malaysian pupils seem to have not master the skill and this have resulted in pupils lacking a good reading skill especially when it comes to English language. Therefore, it is important for the pupils to have a support system which would enable them to make better connection with their reading materials. Thus, the goal of this study is to determine the effectiveness of using infographics to enhance reading comprehension among the primary school pupils with average and weak English language proficiency. The data of this research was gathered through tests before the intervention and after the intervention. The data collected from the test and was analysed. The finding of this research shows that there is a significant rise of the mean score from the pre-test to the post-test. As this research has proven that the use of infographics was effective in enhancing reading comprehension among the pupils, it will benefit the teachers to use the intervention to help the pupils in comprehending their reading text better and into enabling the pupils to experience fun their reading session.

\section{Rese a r ch H igh I ight s}

1. The use of infographics were significantly effective in helping the pupils to understand the English reading text well. Pupils were able to summarise the text well as they can make better meaning out of the text that they are reading.

2. The combination of various modes of communication that is words and images were effective in making the pupils understand the text better.

3. Multiple intelligences played a key role where the researcher's urge to put the pupils' multiple intelligences into consideration to devise the intervention was a success.

4. Pupils were able to make mental representations through the reading materials in the form of texts and also pictures.

\section{Research Objectives}

The aim of this study is to:

1. Determine the effectiveness of the use of infographics in helping pupils in comprehending a text.

\section{Methodology}

This research engages action research as the basis of this research. It focuses of quantitative research. This research uses the Kemmis and McTaggart research design (Kemmis, 2008). This 


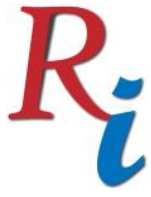

\section{Asia Proceedings of Social Sciences (APSS) \\ www.readersinsight.net/APSS}

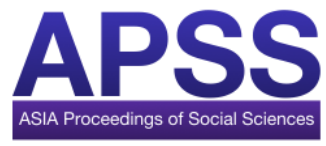

action research is carried out in a semi-urban school in Pahang, Malaysia in the district of Kuantan. Sixteen pupils were chosen as the research participants for this study through purposive sampling. Two sets of lessons were conducted, that is the traditional lesson where the intervention would not be used during this lesson and the intervention lesson where intervention will be employed during this lesson. Both pre-test and post-test were used as the research instrument. These tests were taken by the participants right after their reading session during the traditional and intervention lessons. Quantitative data analysis was used to analyse the data. Data that was collected during the pre-test and post-test were analysed using the SPSS software to compare the mean scores from the pre-test and the post-test.

\section{Results}

The mean scores obtained during the pre-test and post-test shows that the infographics were effective in helping the pupils in understanding their English reading text better. The intervention of using infographics were shown to has significantly improved the pupils' comprehension towards the text through the attainment of scores of 9.6 compared to the overall mean score that was obtained during the traditional lesson where no infographics were used in the lesson was just 4.4. To gain a stronger validity towards the results of this research, a paired sample t-test were employed. The result $(\mathrm{t}=6.23, \mathrm{p}=0.00)$ strongly proves that the use of infographics has enhanced the ability of the pupils to comprehend the text well and grasp the meaning of the text better. The results that has been obtained answered the research question where infographics are effective in helping to improve pupils' reading comprehension.

\section{Findings}

The ability of the pupils comprehending the text better were based from considering many aspects. The combination of various modes of communication (Kress, 2009) that is words and also images has helped the pupils to understand the text better. On top of that, multiple intelligences (Tomlinson, 2001) that was tailored to pupils' need of visual cues has made the results were postive in helping the pupils to understand the text better. Most importantly, the key aspects that is the Cognitive Theory of Mulrimedia Learning (Mayer \& Moreno, 2002) has enable the pupils to make mental representations through the reading materials.

\section{References}

Kress, G. (2009). Multimodality: A social semiotic approach to contemporary communication. In Multimodality: A Social Semiotic Approach to Contemporary Communication. https://doi.org/10.4324/9780203970034

Mayer, R. E., \& Moreno, R. (2002). Aids to computer-based multimedia learning. Learning and Instruction. https://doi.org/10.1016/S0959-4752(01)00018-4 


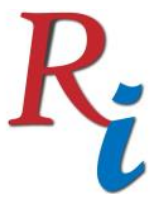

\section{Asia Proceedings of Social Sciences}

(APSS)

www.readersinsight.net/APSS

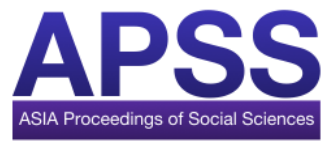

Kemmis, S. (2008). The SAGE Handbook of Action Research 8 Critical Theory and Participatory Action Research 8 Critical Theory and Participatory Action. In The SAGE Handbook of Action Research. https://doi.org/10.4135/9781848607934

Tomlinson, C. A. (2001). How to differentiate instruction in mixed-ability classrooms. In Association for Supervision and Curriculum Development.

Author's Biography

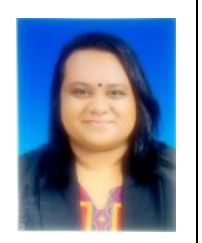

Revathy Manickam is a postgraduate student at the Faculty of Education, Universiti Kebangsaan Malaysia. She graduated in B.Ed TESL from the Teacher's Institute of International Languages, Kuala Lumpur, Malaysia. Currently, she is teaching at a semi-urban school in Malaysia. The focus of her research is main on second language acquisition and strategies employed towards second language acquisition.

ORCID: https://orcid.org/0000-0003-0335-6216

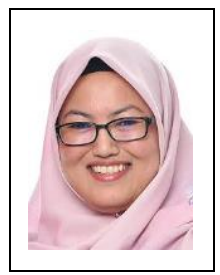

Azlina Abdul Aziz is a TESL lecturer at the Faculty of Education, UKM. She has an Ed.D in Teaching of English from Teachers College, Columbia University, U.S.A. Her research interests are in the Teaching and Learning of Literature and Teacher Education in TESL. She is interested in how literary texts and personal narrative may be utilised to help students to examine the social, cultural and political issues in a particular context.

ORCID: https://orcid.org/0000-0002-7800-3688 